ACTA UNIVERSITATIS LODZIENSIS

FOLIA LITTERARIA POLONICA 5(35) 2016

http://dx.doi.org/10.18778/1505-9057.35.01

Marek Ostrowski*

\title{
Issues of Truth and Correctness vs. Rhetoric in Media Discourse
}

Rhetorical influence can be understood within the media discourse as a result of the strategy adopted by the system. In this context, it is assumed that communication is the primary action which constitutes human communisation. It is impossible to separate the society from the communicational phenomena which define the entirety of its existence. One can only pose the question concerning what was first - social action or communication. It can be assumed, along with what Niklas Luhmann states, that communication constitutes social systems. It takes place within the systems which produce meaning. In the context of the society as a set of systems, the concept of the rationality of actions in the face of contingency processes becomes crucial. The act of formulating the strategy assumes regaining the stability through the system contingents ${ }^{1}$.

A discussion about the fundamental - for media philosophy - concept of truth results from the adopted assumption ${ }^{2}$. The systems within the adopted strategies work in the media using persuasion in a way which stays far from the notion of truth as an idea or an ethical condition ${ }^{3}$.

* Prof., e-mail:mostrowski54@wp.pl; University of Lodz, Faculty of Philology, Department of Journalism and Public Communication; ul. Pomorska 171/173, 90-236 Łódź.

${ }^{1}$ See: N. Luhmann, „Systemy społeczne. Zarys ogólnej teorii”, transl. M. Kaczmarczyk, $2^{\text {nd }}$ ed., rev. ed., Nomos, Cracow 2012. Edyta Pałuszyńska in her book Stategie dziennikarzy i ich rozmówców w medialnym dyskursie publicznym (Wydawnictwo Uniwersytetu Łódzkiego, Lodz 2012) also writes about the rhetorical influence as a function of the system strategy. For those who appear in the media, the necessity to predict logical and practical consequences of the voiced viewpoints is of paramount importance. Such a performance can be also analysed in terms of the rhetoric of contact within the frames of a sociolinguistic idea of a dialogue between a sender and a receiver, which requires taking into consideration the social and historical context of the utterance. Sociolinguists often speak about this conversation and partly dedicate their examination to so-called conversation analysis, which is an actualisation of the sender - receiver contact, taking into account the constant change of the communication poles (A.Linke, M. Nussbaumer, P.R. Portmann, „Studienbuch Linguistik”, 5. rev. ed., Max Niemeyer Verlag, Tübingen 2004).

${ }^{2}$ This article differentiates between the archetypal Aristotelian definition of truth, Heidegger's Aletheia and the truth as simulacrum.

${ }^{3}$ The truth finds its place within the argumentative layer of the text. 
There is an abundance of examples in the media discourse. One may analyse, for instance, the conversations of the Polish parliament's special committees of inquiry concerning the so called Rywin affair or the gambling scandal. They required appropriate strategies from the people responsible for leading the proceedings, from the presidium of the representatives of different political parties, as well as from the people testifying in front of cameras, who were not only responsible for their personal well being, but also for their political party's concerns.

The following extract comes from the proceedings of the gambling scandal committee ${ }^{4}$ :

MP Bartosz Arlukowicz (Left Wing): During our last sitting we instituted Dr Waldemar Gontarski as a regular advisor to the committee. He was appointed on the grounds of a motion, as well as a the chairman's recommendation, in which he presented Dr Waldemar Gontarski. In the written address to the members of the committee, which recommended Dr Gontarski, the chairman states that Dr Waldemar Gontarski is the director of the Legal Expertise Centre of the Polish Lawyers Association, a lecturer at the Faculty of Law and the Faculty of Social Sciences at the University of Finance and Management in Warsaw, has the academic degree of doctor from the University of Warsaw, and that he provides expert opinions for courts, public prosecutors and private legal entities. The chairman, while recommending Dr Gontarski, states also that he is one of the few Polish lawyers who work on aleatory contracts, including those which involve gambling. We unanimously accepted Dr Gontarski's nomination, trusting the document which was presented to the committee. Nevertheless, after the sitting, there appeared some doubts. Because of that, I would like to ask further clarifying questions. Today we have received Dr Gontarski's curriculum vitae, in which it is stated that he has a doctor's degree from the University of Warsaw in humanities. I would like to ask the chairman if he could inform us, in order to clarify our knowledge about Mr Gontarski, about the faculty, field of study and of which sciences is Mr Gontarski a doctor of, apart from the general description - a doctor of humanities. Does the committee know? Does the chairman know?

Chairman MP Miroslaw Sekula (Platforma Obywatelska (the Civic Platform)) All the information presented in the motion nominating Dr Gontarski as an advisor to the committee came from Mr Gontarski. As you know, Dr Gontarski is also an advisor to a different committee of inquiry, and so I had asked among the advisors of the mentioned committee, concerning their willingness to cooperate with us. Because I received Mr Gontarski's acceptance, I filed the motion in his name, basing on the information I was given by him and fully trusting it. On the grounds that Mr Waldemar Gontarski sent us his curriculum vitae with additional information on the day when we were deciding about the post, I trust that this information does not raise doubts

\footnotetext{
${ }^{4}$ Biuletyn no. 9, Kancelaria Sejmu, Biuro Komisji Sejmowych, No 3178/VI term 18.12.2009.
} 
and that we should simply believe Dr Gontarski's declarations. This is the explanation of the origin of my motion, as well as the information I presented to you. Thank you. Marshal of the Sejm Stefaniuk.

MP Franciszek Stefaniuk (Polskie Stronnictwo Ludowe (the Polish People's Party)) I would suggest a departure from judging the curriculum vitae and the person of Mr Gontarski as a candidate for the post of advisor. If the situation were different, if we were to choose one candidate out of five, then I would agree to such a free analysis. Because, however, the committee has carried a resolution of instituting five advisors, and we only have one candidate, we shouldn't belabour the point, for example, because Mr Gontarski is an advisor to a different committee of inquiry which doesn't have any reservations considering him. What we need, nevertheless, is an authoritative knowledge, so this committee, which works openly, has an advisor able to evaluate problematic issues or allay our doubts. If Mr Gontarski is ready and he applies for a job of such character, I suggest we should humbly accept him, as for the past two months the committee hasn't been able to find any other candidate. Thank you.

Chairman MP Mirosław Sekula (Platforma Obywatelska (the Civic Platform)) Thank you. Chairman Arłukowicz.

MP Bartosz Arlukowicz (Left Wing): Mr Stefaniuk, with all due respect, I cannot agree. This is not a situation where the committee shouldn't have all the knowledge about the expert who is to advise us on a very difficult issue - the issue of resolving a serious scandal, a complicated legislative process, which has lasted many years. The Sejm as obliged us to do so. It cannot be that we start our work and vote on the nomination of a person, about whom - in my opinion - we have sketchy knowledge. That is why I will continue to ask. I will do it efficiently and quickly, because we have to return to the most important issue, we have to uncover the scandal. I would like thus to ask - I will finish shortly - about information that cannot be found anywhere in your curriculum vitae or the recommendation. Has Mr Gontarski completed any legal traineeship as an attorney, solicitor, judge, public prosecutor, bailiff or a legislative traineeship? Has Mr Gontarski completed any of the mentioned training?

Chairman MP Mirosław Sekuła (Platforma Obywatelska (the Civic Platform)) Please gather this knowledge on your own ${ }^{5}$.

MP Bartosz Arłukowicz (then from Sojusz Lewicy Demokratycznej (the Democratic Left Alliance)) asks a question, which seemingly derives from a willingness to establish facts (the archetypal definition of truth). Posing the question has, however, the character of undermining the obviousness of the expert's abilities - the expert who was nominated by the committee's chairman Mirosław Sekuła (Platforma Obywatelska (the Civic Platform)) - and this action can be perceived as diminishing Mr Sekuła's status.

\footnotetext{
${ }^{5}$ Ibid., pp. 4-5.
} 
The process of argumentation is a conflict of two viewpoints. Chairman Sekuła, when nominating the expert, clearly states that he perceived him as a competent advisor, while MP Arłukowicz expresses his doubts concerning this decision. The conflict, however, cannot be reduced to a logical true - false scheme. It has a rather pragmatic character - it expresses Mr Arłukowicz's subjective belief, which opposes Mr Sekuła's judgement - and thus it influences the impression of the uncertainty concerning the chairman's thesis. To put the notion within the aspect of image - it lowers his status.

Obviously, the rhetorical subjects could not work effectively not putting their disquisitions within the concept of truth. One should notice, however, that it is not the truth understood as an idea.

The archetypal definition of truth is the most common one. It constitutes the unity of things with the intellect. It remains, as such, within the current state of knowledge - it is a subject of credible judgement. Not every credible judgement, and not every acceptance or denial of a conjuncture can be described as knowledge. That is why one needs, in this Aristotelian take, a certainty, as Edmund Husserl writes in Logical Investigations, the so called "evidence" (Evidenz) that things are truly the way we found them. That certainty is different from the sometimes blind belief, the view one has on a subject.

This certainty thus is a mark of the correct thinking, the truth lies within it. In most cases, one does not need this absolute recognition of truth. Instead, one uses beliefs about the greater or lesser probability of a conjuncture, to which one adds a specific judgement. One can speak thus about an evident likelihood, about evidence of the probability of a conjuncture ${ }^{6}$. The absolute genuineness of the judgement is not based on certainty, however, in it, the comparative and evident evaluative definitions are consolidated. Thanks to these terms one is able to distinguish between a positive and negative probability, and the better and worse justified assumptions. The further this certainty spans, the further the knowledge reaches. Knowledge is a derivative of the evidence - the certainty of the conjuncture happening or not. The certainty that there is a correlation: if S., then P. If one certifies a conjuncture, one creates exact knowledge.

It is worth noticing a confluence of the notions of correctness and truth in this context. In 2004 Lexikon für philosophische und theologische Ethik was published in Germany ${ }^{7}$. The author of the Richtigkeit entry, that is correctness, Micha $\mathrm{H}$. Werner differentiates between the notions of correctness in the common parlance, in the history of philosophy, and within ethics as moral philosophy. His analysis falls within the ambit of the archetypal definition of truth. The concept of

\footnotetext{
${ }^{6}$ Ibid., p. 13.

7 „Lexikon für philosophische und theologische Ethik”, ed. P. van Tongeren, J.-P. Wils, Schöningh Verlag, Paderborn 2004.
} 
correctness, within the common linguistic take, regards identification or qualification of objects or actions, for example, in a sentence uttered by person X: "This hex key is the right one" - is the right key the one about which the speaker is talking, or the one which fulfils the needs of the person at the moment. In a sentence "Telling him the truth wouldn't be right [in this context it means correct - M.O.]" the word "right" expresses the evaluating and qualifying context.

The concept of correctness, understood within the already mentioned Aristotelian definition of truth, refers to different rules and has a vivid normative aspect. The fact that an utterance is correct means also that it is, for example, in agreement with grammatical rules.

Correctness - in the context of value - in regard to the concept of truth is eidetic and teleological. The notion is ventured by the responsibility contained in the concept of truth.

The subject formulates their relation with reality by means of an evaluating judgement. Thanks to it, they decide what is approval-worthy, commonly accepted, worth praising, relatively dismissed, denied, condemned, etc. The judgement: "A man should love all animal beings" expresses a notion that if a person does not do it, they are not a correct - a righteous - human. The statement: "A drama should not chaotically disintegrate into episodes" conditions a judgement that the play from this example is not a good drama, not a correct piece of art. In all these examples the evaluation is based on adding a positive predicate, which is qualified by fulfilling a specific condition. Not fulfilling the condition results in adding a negative predicate. The following forms are thus equivalent: "A should be B", and "A, which is not B, is not a correct A", or "only this A which is B, is the correct A".

The term "correct" serves here in its most broad understanding as a description of something valuable. It especially concerns the actions which are basal for it. They are defined as "usefulness", "beauty", "good morals", etc. The subject, in his image of the world, refers to what should be, appraises the attitudes, investing and giving them specific values ${ }^{8}$. From this analysis it stems that every normative sentence assumes a certain type of values (praise, appreciation), thanks to which there is created a kind of correct or incorrect behaviour towards a certain class of objects. Husserl presents truth and correctness - according to the above mentioned Aristotelian definition of truth - as terms which serve the correlation. The judgement which takes the thing that happened for truth is considered the correct one. It is similar with the notion that correctness can be also understood as an agreement with the norms in the context of justification of human actions.

If one justifies an action, it is said that it is correct because it is harmonious with the norms. Every conscious action thus is consistent with the norms. An

\footnotetext{
${ }^{8}$ Ibid., p. 42.
} 
action can be compliant with the orthographic norms, rules of a game, social conventions, legal rules, etc. (Micha Werner).

Werner Tugendhat distinguishes a concept of correctness which involves an unmitigated justification of an action'. Unmitigated here means that it does not depend on a rule, on a certain partner, but on any partner. It is a so-called legitimacy. Constatives have a direct quality of legitimacy.

All types of actions can be thus legitimized indirectly because "a deliberate action assumes intentions, and these are contained in constatives of a form of 'it is right (correct) to', which also assumes a form of 'it is correct to perform X'". The correctness in this broad context refers to the compliance of an action with the indicated rules, it stands thus in a relation with the norms and values, which constitute the basis for any action.

The issue of truth has to be, as seems obvious, entrenched with numerous necessary conditions, which protect its rationality and logicality.

The groundwork of this rationality was created in ancient times by Plato and Aristotle. Imelda Chłodna writes:

Our utterances about truth (judgements - sentences in the logical sense) have to be, most importantly, internally non-conflicting, that means rational (sensible); utterances internally conflicting have to be uncompromisingly eliminated from the discourse. Rationality of the statement is a necessary condition of the discourse, however, the correctness does not stem from it, as false utterances are grammatically correct and logical, although they do not correspond with the reality. Judgements are true, that is consistent with their subject, according to the classic definition of truth, which states that the truth is a compliance of the intellect and the object. This definition has a logical character, its repeal is logically impossible because every judgement assumes its force out of necessity ${ }^{10}$.

The demeanour of the thinking subject and the decisions they make happen on the basis of the rules of evaluation, which have already been acclaimed and consolidated. The moment of evaluation, of choosing one value over the other is essential for decision making, as the decisions refer to the process of taking an inner ideological stance against a specified phenomena of the surrounding reality. This reality can be described as a multitude of so-called cultural objects "different phenomena within the cultural sphere - people and their behaviour,

${ }^{9}$ E. Tugendhat, „Vorlesungen zur Einführung in die sprachanalytische Philosophie”, Suhrkamp, Frankfurt am Main 1976.

${ }^{10}$ I. Chłodna, „Retoryka klasyczna w kontekście warunków poprawności dyskursu filozoficznego", http://www.sapientiokracja.pl/index.php?option=com_content\&view=article\&id=95:retor yka-klasyczna-a-poprawnoc-dyskursu-filozoficznego\&catid $=38$ :imelda-chodna\&Itemid $=66$ [access: 16.11.2015]. 
institutions and their actions, events, processes and states"11. The sphere can be described by means of the so-called second reality, which is a set of culture creating symbols, and within this culture, there is the thinking subject. The axiological judgements of the specified subject or a social group refer to these objects ${ }^{12}$.

The cultural objects are the arguments in the predicate structure of the axiological judgements. As predicates, they occur in connection with the evaluating judgements. Aleksy Awdiejew understands an ideology as a relatively organized set of generalized axiological judgements which are considered true ${ }^{13}$. He proposes creating an orderly list of the generalized axiological judgements which represent the ideology. These are the prescriptive judgements of the $\mathrm{Qn}(\mathrm{Xn})$ type, which ascribe a specific quality, or descriptive judgements of the $S\{Q n(X n)\}$ type, where S stands for the deontic sense of duty ${ }^{14}$.

If one assumes that the media work mainly coaxingly, then the concept of truth within the existential categories of the subject becomes the basic question, which attests the conjuncture's occurrence or its lack. It has a sense of siding with the convincing totality of features of the specific phenomenon, and it claims that it is internally consistent and convincing - thus true. Propagandistic or promotional activities, as a matter of fact, are to achieve the effect of conviction in the pragmatic understanding. The occurrence of the object's projection presented in an advertisement - for example creating a sense of community with the product consumers, along with the belief of participation in the inner relation with other consumers, who are ascribed a specific feature, for example being communicative, friendly, open or successful - is a feature of the advertisements which work globally in the new media, and create a globally attractive, positive image. The slogan "Nokia connecting people" makes one answer "basically yes" - the totality of the phenomenon is approved when one becomes a member of Nokia's family of consumers ${ }^{15}$.

The truth in this understanding was characterised by Martin Heidegger in the twentieth century.

${ }^{11}$ A. Awdiejew, „Konstruowanie trzeciej rzeczywistości”, in: „Mechanizmy perswazji i manipulacji. Zagadnienia ogólne”, ed. G. Habrajska, Oficyna Wydawnicza Lexem, Lask 2007, p. 95.

12 Ibid.

${ }^{13}$ Ibid.

${ }^{14}$ Ibid. John Austin proves that one cannot ascribe only the logical content to what is spoken. If one says something, it obviously has a logical sense, but also a pragmatic one. There are quite substantial differences between the sentences which can be verified using the truth - false rule and linguistic pragmatics (idem, „Zur Theorie der Sprechakte” [How to do things with words], $2^{\text {nd }}$ ed., Reclam, Stuttgart 1979).

${ }^{15}$ Nokia's Chief Marketing Officer Tuula Rytila states in the article entitled "What 'Connecting People' really means" dated as of $9^{\text {th }}$ April 2013: "Connecting People' is more than a tagline. It's a mission statement that has guided almost everything we've done for over 20 years" (http:// lumiaconversations.microsoft.com/ [access: 15.02.2015]. 
Heidegger's fundamental work Sein und Zeit published in 1927 derives from the works of phenomenology. The crucial philosophical issue, the concept with which the author starts his analysis is "being” - „das Sein". The definition of "being", that is the existence, the life, was the subject of philosophical analysis in ancient times, as one of the most basic problems, however, later on in the history of philosophy, there was a long silence concerning the issue, until Heidegger's appearance at the beginning of the twentieth century. The question of esse-meaning the existence - was not discussed because it belongs to the so-called metaphysical notions. In ancient times the definition of life seemed redundant. The issue was considered an obvious one. In later times, the subject was raised by Blaise Pascal in his Pensées. It also gained importance at the beginning of the nineteenth century in the works of George W. F. Hegel, along with the development of psychology. For Heidegger the starting point is of a linguistic nature. It seems at the beginning of his work that the philosopher takes "Sich zu sich selbst Verhalten" - a hermeneutic behaviour towards oneself, which is expressed primarily in the language - as the foundation of the "Sein" concept. In every linguistic behaviour towards oneself or in the judgements on the phenomena which do not refer to the self, the concept of "being" is used, every sentence is more or less related to the speaking subject's existence. "The sky is blue", "I am happy" - these are sentences whose meaning derives from a subjective experience ${ }^{16}$. Because the meaning of the "das Sein" concept is unclear, the philosopher addresses the linguistic side of humanity. Being is an active linguistic process. The life is the essence of the question, it has a linguistic sense of inquiry. The inquiry, and thus the uncertainty, contains the intention and the willingness to understand. The philosopher writes about it in the chapter entitled "The Formal Structure of the Question of Being"17:

The question itself is the action of the one who exists, who inquires, it has its own sense of esse... Every question is seeking. Every seeking, in its process, is guided beforehand by what is sought. The question is the cognitive seeking of being in its description and essence... The question is always about something, it has its realm ${ }^{18}$.

The fact that Heidegger's theory is not only a form of language criticism is evident in the next passage from the introduction to Sein und Zeit, in which one reads that everything one talks about, and how one acts one way or another in reference to it has "the same nature of being as what we are and how we exist. Being is a part of something determinate, and as such it transpires in reality, occurrences, possession, importance, existence" 19 . The philosopher, ardently ques-

\footnotetext{
${ }^{16}$ M. Heidegger, „Sein Und Zeit”, Max Niemeyer Verlag, Tübingen1986, p. 4.

${ }^{17}$ Ibid., „Die formale Struktur der Frage nach dem Sein”, chap. 2 „Sein und Zeit”.

${ }^{18}$ Ibid., p. 5.

${ }^{19}$ Ibid.
} 
tioning the sense of the concept of "being", stays within the language domain, which is the instrument of expression of the sought notion. Heidegger takes from Husserl's phenomenology also a different possibility of solving the problem, trying to perceive it as a reciprocal reference of acts, which are performed by the transcendental "I" within the consciousness, and the real sphere of the responses to the performed cognitive acts. The domain referring to the images of the vital processes is rooted in the relationship of the discussion and the true reality ${ }^{20}$. For Heidegger the truth is the esse. He understands the truth in the context of existence, adequately to his own translation from ancient Greek, as something "live, disclosed" - aletheia (Unverborgenheit) ${ }^{21}$. As the esse, the truth has to be practiced and experienced. The subject, by means of their being, testifies that the truth takes place and happens. It has the character of an ascertainment, which refers to the totality of the occurrence and the experience. It is an occurrence and a way of assuming an attitude on the basis of the experience. This way, in accordance with Heidegger, one is able to evaluate the ideology which was experienced in practice as an occurring worldview horizon. And they testify this occurrence. It is a consistent inner overview - an insight into an idea, phenomenon, experience. The phenomena have their taste, smell, a specific shape - they occur - states the subject. It forms the basis for taking the approbatory stance.

Another notion referring to the concept of truth is the existence of the socalled simulacrum. As Jean Baudrillard writes in his numerous works on the subject, simulacrum has no relevancy to the truth - it is the truth itself, which can testify that the truth does not exist. It - the simulacrum - is the truth ${ }^{22}$.

As a model of simulation allegory, the author uses a story about ancient cartographers, who did not have the proper technical devices to reach every destination and to adequately put the data on the maps. The cartographers thus mostly drew maps in such a way that it presented the whole territory, nevertheless, it had little to do with its real state. The kingdom on the map consists of only few miserable buildings in a desert, however, the map itself shows a metaphysical beauty of this ruined reality - it builds the imperial pride, reflecting the substance of the image, and not the reality. It is similar to the contemporarily created images,

${ }^{20}$ See: ibid. H.-G. Gadamer in his work Truth and Method points out that the existence can be defined as a live understanding of the experienced acts of consciousness (See: idem, „Prawda i metoda. Zarys hermeneutyki filozoficznej” [Truth and Method], transl. B. Baran, Wydawnictwo Interesse, Cracow 1993, chap. „Przygotowanie historyczne”, subch. „Przezwyciężenie zagadnień teoretycznopoznawczych przez badania fenomenologiczne"). In this text, for Gadamer, Heidegger serves as an example of the necessity to combine the unity, the continuity of the reflection process in the course of the understanding acts, and the pure existence, the same humane being as an individual and specific domain, where the hermeneutics is a real life process.

${ }^{21}$ In this context it is the poetic truth.

${ }^{22}$ See: J. Baudrillard, "Simulations", Columbia University, New York 1983, pp. 1, 4-5, http:// www.ee.sun.ac.za/ hgibson/docs/html/Simulacra_and_Simulation.html\#c2 [access: 12.02.2015]. 
which are to clarify or explain the reality which one is trying to understand. Baudrillard describes modern civilisation's attempts to recreate the life of the newly found primitive tribes, which live the same way as they did thousands of years ago, when there was no ethnography. A tribe, which is moved from a jungle, is given living conditions similar to their natural ones - something comparable to the original conditions in which the tribe used to live. Of course the original living conditions of the tribe will never occur. They are recreated by the contemporary civilisation, the way it thinks they used to look. It is impossible to recreate the original. The tribe cannot be understood in any other way than by means of the contemporarily accessible terms. Science thus works within the set of suppositions, assumptions and hypotheses. It becomes a pure enchantment, magic, as the philosopher writes - a simulacrum of the first degree.

Today the map - that is the mirror reflection connected with the concept - is not the abstraction. The simulation is not the reflection of the territory resembling its esse or substance. It is the generation of the models of reality without their originals or their true reality. It is a peculiar hyper-reality. The territories no longer need maps, they do not use them. These are the maps that mark and set the territories. It is the reality, not the map, that is the substitute. Baudrillard writes that the desert does not consist of the true emptiness of the Roman Empire, but of our own. Something very important has disappeared with time. It is the independent and objective difference between the reality and the simulation. This was the essence of the enchantment. This difference created the poetry of the map and the appeal of the territory, the magic of the abstraction and the charm of the reality. This image of the map representing the area together with the lacking correspondence between one unit and the other, which results from the imperfect work of the cartographer, disappears along with the simulation, whose essence is the core and the succession of matters, and not the discussion and assumptions. The metaphysics recedes. There is no phenomenon of a mirror reflecting beings and phenomena. There is no reality and no concept of transformation. There is no imaginary coexistence, no parallelism of occurrences. The reality is produced from microminiaturized units, models, templates, memory banks, and by means of them it can be reproduced infinite times. It does not have to be rational, since it is not compared to an ideal or some negative reference.

In this context the media use not a direct reference to the reality, but the working, operating units. They create a hyper-reality. And this hyper-reality is the simulacrum. The passed unit is created by the image, which has a loose connection with the reality. The combination of different models of the reality is the product of the synthesis. The created space is not the reality, it is not the rule of the reality. The simulation eliminates all referential points. It becomes a system of signs, their combinatorial equivalence. As the philosopher states, one does not deconstruct the simulation in order to state one's possessions. It is the other way 
round: one creates simulacrum to have what they are lacking. It does not imply the owning, but rather its absence.

The simulation derives from the rule of utopia as the equivalence of the reality, and from the radical denial of the sign as a value. The sign is the reversal and the lifeless sententia of the reality. The moment one recreates the representativeness of phenomena, trying to incorporate the simulation and interpreting it as a false representation, the simulation unfolds the whole mirage of being a reality in itself - it becomes simulacrum.

Gradual phases of the image creation are as follows:

- at the beginning it is a reflection of the original reality

- it masks and transforms the original reality

- it masks the absence of the original reality

- it does not show any connection with any reality. It becomes a pure simulacrum $^{23}$.

It is an evolution from a sign which defines something to a sign which states that there is nothing apart from the sign itself. A longing is developed, a myth of the original, a second-hand truth, an alleged objectivity, an almost-authenticity.

Coming back to the example from the gambling scandal committee - the phenomenon of simulacrum is connected with the (even short-term) creation of the supposed phenomena in the media, whose occurrences are not yet certain. The coverage from the committee's sessions, even not willingly, had to suggest the occurrence of the scandal, for which no one was deemed responsible in the light of the legal arrangements ${ }^{24}$.

${ }^{23}$ Ibid., p. 5.

${ }^{24}$ As one reads in the summary written by the journalists of Wiadomości Onet [Onet News]: “The so-called gambling scandal emerged on $1^{\text {st }}$ October 2009. According to CBA (the Central Anti-Corruption Bureau) the then prominent politicians from Platforma Obywatelska (the Civic Platform): Zbigniew Chlebowski, the president of the Civic Platform parliamentary club, and Mirosław Drzewiecki, the Minister of Sports, were to cooperate - during their collaboration on the changes in the Act on Games and Mutual Wagering - in favour of the businessmen from the gambling industry. The businessmen were supposed to aim at not implementing the proposed surcharges to the games not covered by the public monopoly, for example to the games on lowvalue-prize machines. Following the publication on the issue in «Rzeczpospolita», a political scandal broke; the opposition wanted to institute a committee of inquiry, and it was appointed on $4^{\text {th }}$ November. The parliamentary investigation lasted ten months. Its culmination point was the interrogation of Mr Chlebowski, Mr Drzewiecki and the businessman Ryszard Sobiesiak. The Sejm postponed the date of the completion of the work many times, as initially it was to be the end of February 2010. At the beginning of August the investigators accepted a report of their work, not without controversies and quarrels. After introducing the amendments, however, no one approved of the adopted text. The MPs pointed out its inconsistency. The opposition described it as humiliating and scandalous. As a consequence, the MPs submitted four separate depositions. Investigators from PiS (Law and Justice), Lewica (Left Wing), PSL (the Polish People's Party) and PO (the Civic Platform) presented their own versions of events. The opposition pointed to the PO (the Civic Platform) politicians' illegal lobbying during their work on the Act on Games and 


\section{Conclusion}

Every concept of truth known to philosophy concerns the phenomena which occur in the media and media communication. The most crucial, however, is the ethical aspect of truth. It seems, nonetheless, that, in practice, the vital role of media ethics is reduced as a result of the nature of media activities, which, by definition, pursue the strategies of systems producing the media meaning.

\section{Bibliography}

Austin J., „Zur Theorie der Sprechakte” [How to do things with words], $2^{\text {nd }}$ ed., Reclam, Stuttgart 1979. Awdiejew A., „Konstruowanie trzeciej rzeczywistości”, in: „Mechanizmy perswazji i manipulacji. Zagadnienia ogólne”, ed. G. Habrajska, Oficyna Wydawnicza Lexem, Lask 2007, pp. 95-104. Baudrillard J., "Simulations", Columbia University, New York 1983, http://www.ee.sun.ac.za/ hgibson/ docs/html/Simulacra_and_Simulation.html\#c2 [access: 12.02.2015].

Biuletyn no. 9, Kancelaria Sejmu, Biuro Komisji Sejmowych, No 3178/VI term 18.12.2009.

Chłodna I., „Retoryka klasyczna w kontekście warunków poprawności dyskursu filozoficznego”, http://www.sapientiokracja.pl/index.php?option=com_content\&view=article\&id=95:retory ka-klasyczna-a-poprawnoc-dyskursu-filozoficznego\&catid=38:imelda-chodna\&Itemid=66 [access: 16.11.2015].

Gadamer H.-G., „Prawda i metoda. Zarys hermeneutyki filozoficznej”, transl. B. Baran, Wydawnictwo Interesse, Cracow 1993.

Heidegger M., „Sein Und Zeit”, Max Niemeyer Verlag, Tübingen 1986.

K Le, „Komisja hazardowa: raport i zdania odrębne”, http://wiadomosci.onet.pl/kraj/komisja-hazardowa-raport-i-zdania-odrebne/4914q [access: 15.02.2015].

„Lexikon für philosophische und theologische Ethik”, ed. P. van Tongeren, J.-P. Wils, Schöningh Verlag, Paderborn 2004.

Linke A., Nussbaumer M., Portmann P.R, „Studienbuch Linguistik”, 5. ed., rev. ed., Max Niemeyer Verlag, Tübingen 2004.

Mutual Wagering. Meanwhile, a completely different thesis can be found in the main report. The draft assessment report of the committee's work, prepared by the chairman Mirosław Sekuła (PO (the Civic Platform)), was presented in mid-July. The politician wrote that there are no grounds in the so called gambling scandal for notifying the public prosecutor's office, although he assessed that Zbigniew Chlebowski broke the parliamentary standards, and - as he wrote - the committee «does not believe» the words of Mirosław Drzewiecki. According to Mr Sekuła's project, the Bureau itself was responsible for the information leak about the CBA's (the Central Anti-Corruption Bureau) action considering the so-called gambling scandal. At the beginning of August, the MPs adopted the amendments to the text. The report, which was created this way, states that the PO (the Civic Platform) politicians did not take part in the illegal lobbying concerning the Act, although their testimonies are at times not credible, and that the entity responsible for the information leak about the CBA's (the Central Anti-Corruption Bureau) action might be equally the Bureau itself or the Prime Minister's Office” (K Le, „Komisja hazardowa: raport i zdania odrębne”, http://wiadomosci.onet.pl/kraj/komisja-hazardowa-raport-i-zdania-odrebne/4914q [access: 15.02.2015]). 
Luhmann N., „Systemy społeczne. Zarys ogólnej teorii”, transl. M. Kaczmarczyk, $2^{\text {nd }}$ ed., rev. ed., Nomos, Cracow 2012.

Pałuszyńska E., „Strategie dziennikarzy i ich rozmówców w medialnym dyskursie publicznym”, Wydawnictwo Uniwersytetu Łódzkiego, Lodz 2012.

Rytila T., "What 'Connecting People really means", http://lumiaconversations.microsoft.com/ [access: 15.02 .2015$]$.

Tugendhat E., „Vorlesungen zur Einführung in die sprachanalytische Philosophie”, Suhrkamp, Frankfurt am Main 1976.

\section{Marek Ostrowski}

\section{Issues of Truth and Correctness vs. Rhetoric in Media Discourse}

\section{(Summary)}

Following Niklas Luhmann, the author assumes that communication creates social systems. The system therefore influences the nature of communication. The impact of rhetoric on media discourse can be understood as a result of the strategy adopted by the system.

What follows from the above assumption is a discussion of the notion of truth which is fundamental to media philosophy. Systems, in their adopted strategies, affect the media and use persuasion in a way that is remote from the treatment of the truth as an idea or as a condition of an ethical nature.

Keywords: communication, concept of truth, media. 